\title{
Radiotherapy for Renal Rhabdoid Tumor: A Case Report and a Review of Literature
}

\author{
Renal Rhabdoid Tumorde Radyoterapi: Vaka Sunumu ve Literatür \\ Derlemesi
}

\author{
Süheyla Aytaç Arslan', İpek Pınar Aral ${ }^{1}$, Derya Özyörük², Suna Emir², Zeliha Güzelküçük², \\ Arzu Yazol Erdem² \\ ${ }^{1}$ Ankara Atatürk Training and Research Hospital, Ankara, TURKEY \\ ${ }^{2}$ Ankara Children's Hematology and Oncology Hospital, Ankara, TURKEY
}

Dergiye Ulaşma Tarihi:05.12.2017 Dergiye Kabul Tarihi:14.05.2018 Doi: 10.5505/aot.2018.37132

\section{ÖZET}

Renal rhabdoid tumor, çok nadir görülen ve kötü sağkalımla seyreden bir hastalıktır.Radyoterapi bu tumorlerde primer tumore veya cerrahi yatağa, hastalık kontrolü için sıklıkla uygulanmaktadır. Bu vaka takdiminde, 4 aylık renal kitlesi ve yaygın intraabdominal metastazı olan hasta sunulacaktır.Hastaya öncelikle maksimal debulking cerrahi ardından kemoradyoterapi uygulanmıştır. Hastalık progresyon göstermiş ve hasta 3 ay içerisinde kaybedilmiştir.Hastalığı evresine ve hastanın yaşına göre değişik do ve fraksiyonasyonlar uygulanabilmektedir. Doz, fraksiyon ve alan hastaya göre belirlenmelidir.

Anahtar Kelimeler: Renal Rhabdoid Tumor, Radyoterapi, Pediatri

\begin{abstract}
Renal rhabdoid tumor (RTK)s are rare aggressive cancers with poor prognosis. Radiotherapy is a part of disease management and usually applied to the primary tumor or surgical bed. The our case is a 4- month-old female who has kidney tumor with multiple intraabdominal metastases. Maximal debulking surgery was performed and chemoradiotherapy were administered. The patient died in 3 months due to progressive disease after radiotherapy. Different doses are delivered according to age and stage. Appropriate dose, side and fractionation schedule should be determined for every patient.
\end{abstract}

Keywords: Renal Rhabdoid Tumor, Radiotherapy, Pediatric

\section{INTRODUCTION}

Rhabdoid tumours (RTs) are rare aggressive cancers presenting in infants and young children and usually occur in the central nervous system (CNS) (atypical-teratoid RT $=\mathrm{ATRT}$ ), in the kidney (RT of the kidney=RTK), or in the non-CNS, nonrenal soft tissues (malignant RT= MRT) (1). Only $2 \%$ of childhood renal cancers are RTK, and $80 \%$ of them are diagnosed under 2 years of age $(2,3,4)$. RTKs are accompanied with brain lesions approximately $10-15 \%$. RTKs also had poor prognoses like ATRT with overall survival rates of not more than $20 \%$ to $25 \%$ (3). The median age is 10.6 months and a male to female ratio of 1.37 (1). Most common site of metastasis is lung (5). We present a case of RTK treated with radiotherapy in our Radiotherapy Clinic and reviewed the literature of the last 32 years.

\section{Review of Literature}

We searched the PubMed database (National Library of Medicine, http:// www. ncbi.nlm.nih.gov) between january 1984 to May 2016, using the following search terms renal, rhabdoid tumor, pediatric. The studies which have definite data about radiation dose and fractionation were included. Five articles were identified with 10 (included our cases) patients that treated with radiotherapy with diagnosed RT (Table 1). 
Table 1. Review of the Literature.

\begin{tabular}{|c|c|c|c|c|c|c|c|c|}
\hline Case & Sex & $\begin{array}{l}\text { Age } \\
\text { Mo }\end{array}$ & Stage & Surgery & Chemotherapy & Radiotherapy & $\begin{array}{l}\text { Time to } \\
\text { progresion }\end{array}$ & $\begin{array}{l}\text { Vital } \\
\text { Status }\end{array}$ \\
\hline $1(7)$ & $\mathrm{F}$ & 108 & 2 & Delayed & Carbo/VP+C & 1080cGy & None & $\begin{array}{l}\text { NED } \\
78 \\
\text { mo }\end{array}$ \\
\hline $2(7)$ & $\mathrm{M}$ & 21 & $\begin{array}{l}3 \text { (lymph } \\
\text { nodes) }\end{array}$ & Upfront & VAdriaA+CDDP/VP & 2400 cGy & $\begin{array}{l}7 \mathrm{mo} \\
\text { (local and Lung) }\end{array}$ & $\begin{array}{l}\text { DOD } \\
9 \mathrm{mo} \\
\end{array}$ \\
\hline $3(7)$ & M & 96 & $\begin{array}{l}\text { (lung } \\
\text { metastasis) }\end{array}$ & Delayed & $\begin{array}{l}\text { CPPD/adriamisin+ifo } \\
\text { s/VP +VAC }\end{array}$ & $1400 \mathrm{cGy}$ & $\begin{array}{l}6 \text { mo } \\
\text { (Lung) }\end{array}$ & $\begin{array}{l}\text { DOD } \\
6 \mathrm{mo}\end{array}$ \\
\hline $4(6)$ & $\mathrm{M}$ & 4 & Localized & Upfront & $\mathrm{Cp}, \mathrm{VP}, \mathrm{C}$ & $1050 \mathrm{cGy}$ & $\begin{array}{l}11 \mathrm{mo} \\
\text { (Brain) }\end{array}$ & $\begin{array}{l}\text { DOD } \\
12 \\
\text { mo } \\
\end{array}$ \\
\hline $5(6)$ & $\mathrm{M}$ & 5 & Localized & Delayed & $\begin{array}{l}\text { ACD VCR - ACD } \\
\text { VCR DCp, VP,C }\end{array}$ & $1800 \mathrm{cGy}$ & None & $\begin{array}{l}\text { NED } \\
9 \\
\text { years }\end{array}$ \\
\hline $6(6)$ & $\mathrm{M}$ & 4 & Localized & Upfront & $\begin{array}{l}\text { Cp, VP,C -VDC-Ifos } \\
\text { Cp, VP,C M VP Cp- } \\
\text { HSCT }\end{array}$ & $2160 \mathrm{cGy}$ & None & $\begin{array}{l}\text { NED } \\
4 \\
\text { years }\end{array}$ \\
\hline $7(12)$ & $\mathrm{M}$ & 5 & 4 & Upfront & VCR, epi, VP16, ifo & $2400 \mathrm{cGy}$ & $\begin{array}{l}3 \mathrm{mo} \\
\text { (lymph Nodes) }\end{array}$ & $\begin{array}{l}\text { DOD } \\
3 \mathrm{mo}\end{array}$ \\
\hline $8(11)$ & $\mathrm{M}$ & 5 & 4 & Upfront & $\begin{array}{l}\text { ACD VCR -ICE - } \\
\text { HSCT (thiotepa and } \\
\text { melphalan) }\end{array}$ & $1080 \mathrm{cGy}$ & $\begin{array}{l}6 \text { mo } \\
\text { (Lung) }\end{array}$ & $\begin{array}{l}\text { NED } \\
5 \\
\text { years }\end{array}$ \\
\hline $9(2)$ & $\mathrm{M}$ & 24 & 3 & Delayed & $\begin{array}{l}\text { VCR, } \\
\text { DOX,ACD,C,IFO,CB } \\
\text { DCA, VP, THP-ADR } \\
\text { HSCT }\end{array}$ & $1080 \mathrm{cGy}$ & None & $\begin{array}{l}\text { NED } \\
3 \\
\text { years }\end{array}$ \\
\hline $\begin{array}{l}10 \\
\text { (our } \\
\text { case) }\end{array}$ & $\mathrm{F}$ & 4 & 3 & Upfront & VCR,C,İfos,Cp,VP & $1080 \mathrm{cGy}$ & $\begin{array}{l}3 \text { mo } \\
\text { (İntraabdomina) }\end{array}$ & $\begin{array}{l}\text { DOD } \\
6 \mathrm{mo}\end{array}$ \\
\hline
\end{tabular}

F: female, M: male, Died of disease:DOD, no evidence of disease :NED, cGy: centiGray, VP:etoposid, İfos:ifosfomide, CDDP:cisplatin, C: cyclofosfomide, VCR:vincristine, ACD:Actinomisin-D, THP-ADRprirubicin,HSCT:hematopoetik stem cell transplation, frc:fraction, Epi: epirubicin, Cp:Carboplatin, D:doxorubicin, M:melphalan

Table 2. Radiotherapy Doses and Volumes for Rhabdoid Tumor

\begin{tabular}{|c|c|c|c|}
\hline & Indication & Target Volumes & Doses \\
\hline $\begin{array}{l}\text { Flank } \\
\text { Radiotherapy }\end{array}$ & Stage 1-3 & $\begin{array}{l}\text { The GTV (gros tumor volume) } \\
\text { kidney }+ \text { associated tumor } \\
\text { (according to preoperative CT) } \\
\text { CTV=GTV }+1 \mathrm{~cm}\end{array}$ & $\begin{array}{l}19.8 \mathrm{~Gy} \text { for older than } 1 \text { year } \\
10.8 \mathrm{~Gy} \text { for younger than } 1 \\
\text { year }\end{array}$ \\
\hline $\begin{array}{l}\text { Whole } \\
\text { Abdominal } \\
\text { Radiotherapy }\end{array}$ & $\begin{array}{l}\text { Preoperative } \\
\text { intraoperative tumor } \\
\text { rupture } \\
\text { Stage } 3 \text { patients with } \\
\text { have ascites positive for } \\
\text { rhabdoid tumor } \\
\text { Peritonela seeding }\end{array}$ & $\begin{array}{l}\text { Whole peritoneal cavity } \\
\text { CTV: Superior: } 1 \mathrm{~cm} \text { above the } \\
\text { diapragma } \\
\text { Lateral: } 1 \mathrm{~cm} \text { placed beyond the } \\
\text { abdominal wall } \\
\text { Inferior: Bottom of the foramen } \\
\text { obturatorium( protect the femoral } \\
\text { heads) }\end{array}$ & $\begin{array}{l}19.5 \text { Gy } / 1.5 \text { older than one } \\
\text { year old } \\
10.5 / 1.5\end{array}$ \\
\hline Lung & $\begin{array}{l}\text { Lung metastasis with } \\
\text { older than three years old }\end{array}$ & $\begin{array}{l}\text { GTV: tumor } \\
\mathrm{CTV}=\mathrm{GTV}+1 \mathrm{~cm}\end{array}$ & $15 \mathrm{~Gy}$ \\
\hline Liver & Liver metastasis & $\begin{array}{l}\text { GTV: tumor } \\
\text { CTV }=G T V+1 \mathrm{~cm}\end{array}$ & $19.8 \mathrm{~Gy}$ \\
\hline Bone & Bone metastasis & $\begin{array}{l}\text { GTV: tumor } \\
\text { CTV=GTV+1cm }\end{array}$ & $25.2 \mathrm{~Gy}$ \\
\hline
\end{tabular}

Adress for correspondence: Yard. Doç. Dr. Süheyla Aytaç Arslan Ankara Atatürk Training and Research Hospital, Ankara, TURKEY 


\section{CASE REPORT}

Previously healthy 4-month-old female presented with hematuria. Physical examination showed right abdominal mass $6 \times 5$ $\mathrm{cm}$ in size. The patient's weight was $6 \mathrm{~kg}$, and the height was $60 \mathrm{~cm}$. In USG, $91 \times 78 \mathrm{~mm}$ heterogeneous mass that located in the middle part of the right kidney and multiple intraabdominal lenfadenopathies were observed. Abdominal computed tomography (CT) showed a mass in the right kidney with multiple intra-abdominal lenfadenopathies. The abdominal aorta was displaced to the left. Necrosis was seen in the tru cut biopsy. She was operated and the right kidney and nearby hilar lymph nodes were removed. Pathological examination demonstrated a $8.5 \times 7.4 \mathrm{~cm}$ mass that was negative for desmine, chromogranin, NSE, CD34, CD3, CD45, EMA. Diffuse operative spill and peritoneal seeding were not occured. Rhabdoid morphology cells with large vesicle nuclei, large cytoplasm were observed. Hemorragia and necrosis areas were seen in the tumor. The tumor invasion of the perirenal fat tissue was observed. Kidney invaded by the tumor almost totally with positive resection margins in multiple areas. Only one of the 4 lymph nodes was metastatic. Chemotherapy was started according to EURHAB 2015 protocols with vincristine and cyclophosphamide alternating with ifosfamide, carboplatine and etoposide after nephrectomy. RT was started after two courses of CT. The residual tumor was monitored while RT was being planned. Right flank radiotherapy was delivered to a dose of total 10.8 Gy per 6 fractions with TomoTherapy (Figure 1). 1.8 Gy / fraction is used, because the patient is older than 6 months and limited radiation area. Treatment was well tolerated, without no acute side effects. Four days after the end of the RT, the patient was hospitalized for the third cycle of CT. During this period, the patient developed abdominal distension. The control abdominal CT revealed a $5 \times 7 \mathrm{~cm}$ relapse mass. In addition, newly developed multiple lung metastasis was observed. The patient was admitted in the progression and resistant to chemoradiotherapy. The patient was considered inoperable. 2 cycles of ifosphamid, carboplatine and etoposide (ICE) were applied. Progression to pulmonary metastases, and newly developed liver metastasis were observed after 2 cycles of CT evaluation. The patient developed dispnea. The patient died in 3 months, after the RT due to progressive disease. No autopsy was performed.

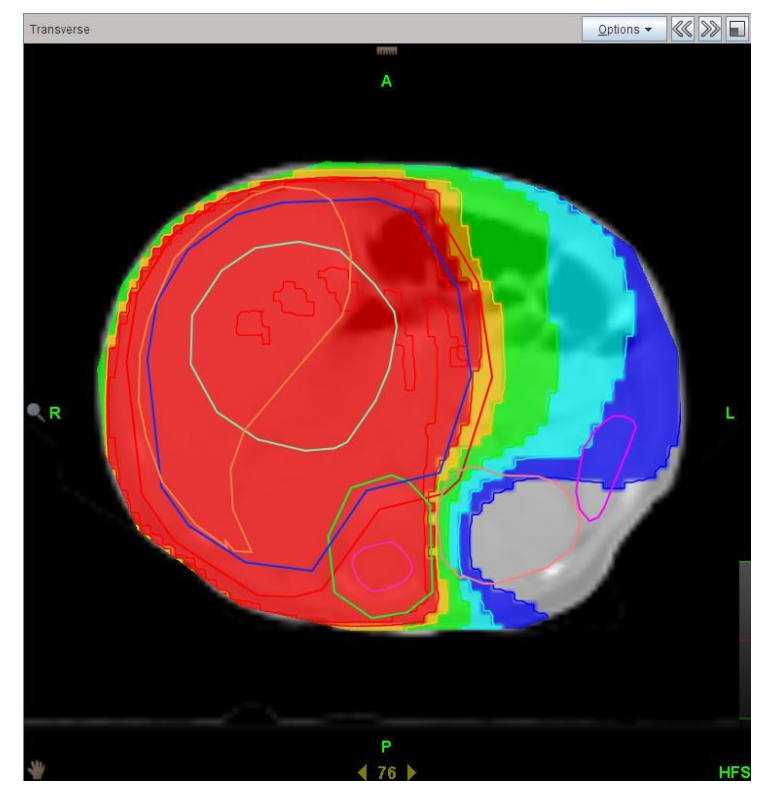

Figure 1. Right flank radiotherapy was delivered to a dose of 10.8 Gy with TomoTherapy. The contralateral kidney must be protected as much as possible.

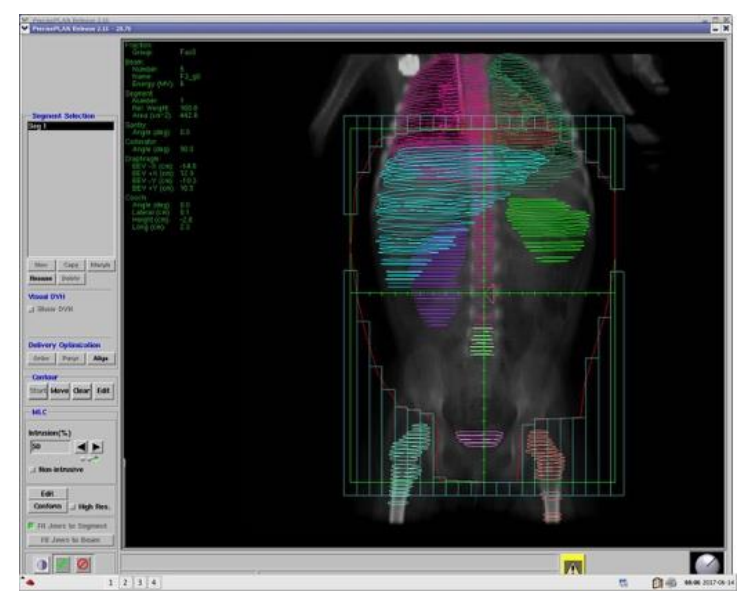

Figure 2. Whole abdominal Radiotherapy was applied, the clinical target volume will be the $1 \mathrm{~cm}$ above the diaphragm to the bottom of the foramen obturatorium and the femoral heads should be protected. 


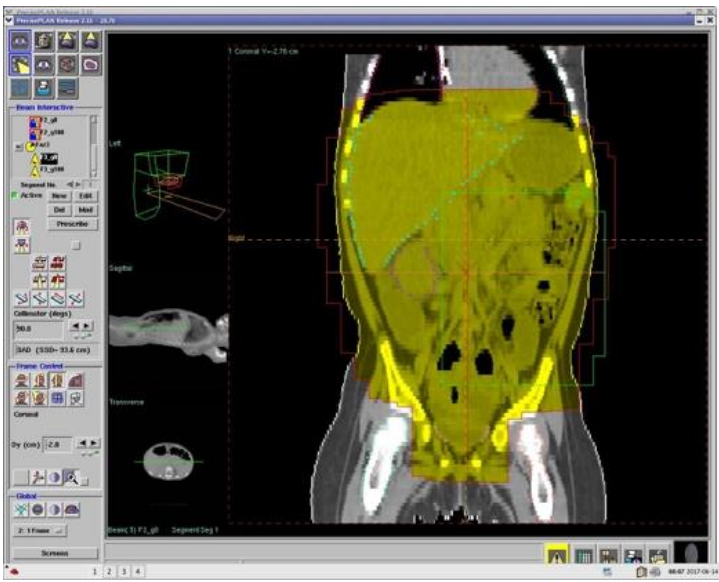

Figure 3. Indications for abdominal radiotherapy are stage III - ascites positive for rhabdoid cells, preoperative tumor rupture, diffuse operative spill and peritoneal seeding.

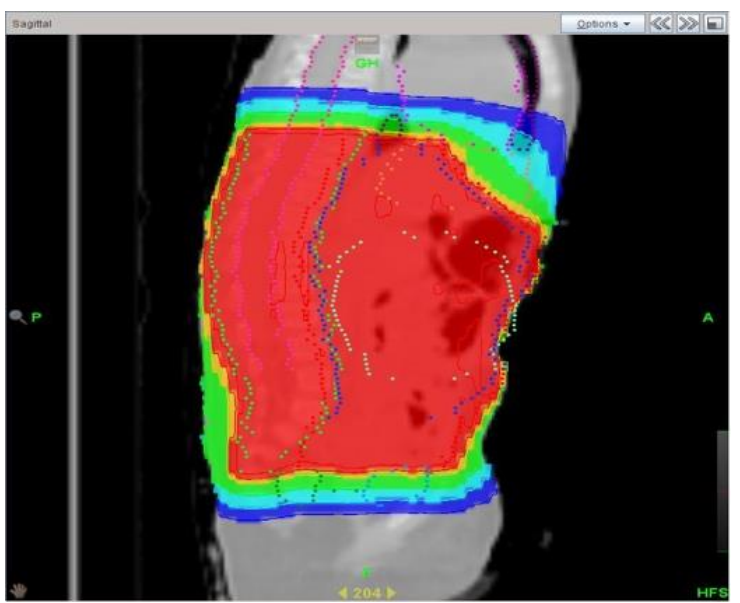

Figure.4 We were paid to the homogeneous dose of all vertebral near the PTV to avoid scoliosis.

\section{DISCUSSION}

RTK is usually treated with surgery and chemotherapy. Response to chemotherapy, complete surgical resection, histopathological factors, tumor stage and additional radiotherapy are associated with outcome. Metastatic disease at diagnosis is associated with poorer outcome $(4,7,8)$. Low stage tumors, an absence of CNS lesion, response the chemotherapy, gross total resection and older than 1 year of age at diagnosis have a better prognosis $(2,3)$. It is difficult to evaluate the effect of radiation on the outcome. Tomlinson et al. evaluated 142 patients with RTK (3). In this study 100 patients received radiotherapy to primary tumour bed. Overall survival at 4 years was $28 \%$ in patients who received radiotherapy and $12.2 \%$ in unirradiated patients. $(\mathrm{p}=0.25)$ They underlined improved survival with radiotherapy in certain subgroups e.g children above the age of 1 year or irradiated to greater than 25 Gy. However, corrected analysis for age did not correlate with this finding. Different doses are delivered according to age and stage (1050cGy-4500cGy) (6,7). Additionally, Sultan et al. analyzed MRT data from the SEER-database for all age and they found that survival for patients between 2 to 18 years was better than another age group (8). There is needed a randomized trial of radiation versus no radiation in infants over the age of 1 year (3). Almost all patients of MRT undergo at surgical resection and usually gross total resection (GTR) is not possible. GTR seems to be a favorable factor for good outcome for MRT (4). Similarly, Hilden et al. in their series of AT/RT describe that patients with GTR have longer survival and EFS than patients who had initial partial resection or biopsy (9). Cases with long time survival are usually patients who have undergone GTR or have undergone aggressive chemotherapy without GTR. Additionally, second look surgery or local therapeutic measures such as gammaknife were suggested for relapsed patients (4). There are no internationally accepted RTKspesific chemotherapeutic(CT) protocol, guidelines recommend "EU-RHAB" currently (doxorubicin, ifosfamide, carbo platinum, etoposide, vincristine, actinomycine $\mathrm{D}$, and cyclophosphamide) $(4,6)$. Even if MRT is chemosensitivite and downstaging and downsizing of tumor is possible, preoperative chemotherapy does not improve survival. So, delay in surgery can lead to worse outcome as compared to upfront resection (5). Radiotherapy is delivered 1.8 Gy per day, except in younger children who treated large volumes (e.g. whole lung or abdomen), that time, usually were delivered 1.5 Gy per day $(6,10)$. We used 1.8 Gy in our case, because of the patient older than 6 months. RT is usually applied to the primary tumor or surgical bed with margins. Flank radiotherapy usually was applied patients with stage 1-3 (19.8 Gy for children $\geq 12$ months, 10.8 Gy for patients $<12$ months). (Figure 1). Abdominal radiotherapy is indicated for stage III - ascites (positive for rhabdoid cells), preoperative tumour rupture, diffuse operative spillage and peritoneal seeding (Figure 2,3). The target volume is 
determined according to the initial pretherapeutic CT or MRI scan. The clinical target volume (CTV) is described as the GTV $+1 \mathrm{~cm}$ and planning target volume (PTV) is described as the CTV $+1 \mathrm{~cm}$. In the case, we determined CTV as flank area. When treatment is planned, attention should be paid to the homogeneous dose of all vertebral near the PTV to avoid scoliosis (Figure 4). The contralateral kidney must be protected as much as possible. In the patients with positive lymph nodes, radiation field is extended to the paraaortic area. When whole abdominal Radiotherapy was applied, the clinical target volume will be the $1 \mathrm{~cm}$ above the diaphragm to the bottom of the foramen obturatorium and the femoral heads should be protected 3 (figure 2). Boost irradiation may be used for patients with gross residual tumor at a total dose of $10.8 \mathrm{~Gy}$. Different doses are applied to different metastatic areas (15 Gy for lung metastases, 19.8Gy for liver metastases, 21.6 Gy for brain metastases plus the boost of 10.6 Gy, 25.2 Gy for bone metastasis) (Table 2) (10). Despite the late term side effect of radiation, recent data appear to support that radiotherapy may be beneficial for MRT $(6,8)$. Vast majority of patients are very young, local radiation is a possible omitted patient who has complete resection for eliminating the late effect of radiotherapy (7).

\section{Conclusion}

Although the radiotherapy side effect, current studies support it. Appropriate dose, site and fractionation schedule should be determined for individual every patient.

Funding: No funding was received for this research.

Acknowledgment: We wish to thank to Mrs. Derya Deniz Şahin, for her valuable contributions of English translation.

Conflict of Interest: All authors certify that they have no affiliations with or involvement in any organization or entity with any financial interest (such as honoraria; educational grants; participation in speakers' bureaus; membership, employment, consultancies, stock ownership, or other equity interest; and expert testimony or patent-licensing arrangements), or non-financial interest (such as personal or professional relationships, affiliations, knowledge or beliefs) in the subject matter or materials discussed in this manuscript.

The next of kin/guardians have consented to the submission of these case reports to the journal.

\section{REFERENCES}

1. Geller JI. Current standards of care and future directions for "high-risk" pediatric renal tumors: Anaplastic Wilms tumor and Rhabdoid tumor. Urologic Oncology: Seminars and Original Investigations 2016; 34: 50-6

2. Koga Y, Matsuzaki A, Suminoe A, et al. LongTerm Survival After Autologous Peripheral Blood Stem Cell Transplantation in Two Patients with Malignant Rhabdoid Tumor of the Kidney. Pediatr Blood Cancer 2009; 52:888 - 90

3. Tomlinson GE, Breslow NE, Dome J, et al. the Rhabdoid tumor of the kidney in National Wilms tumor study: Age at diagnosis as a prognostic factor. J Clin Oncol 2005; 23:7641-5

4. Kerl K, Holsten T, Fruhwald MC. Rhabdoid Tumors: Clinical Approaches and Molecular Targets for Innovative Therapy. Pediatric Hematology and Oncology 2013; 30:587-605

5. Heuvel-Eibrink MM, Tinteren $\mathrm{H}$, Rehorst $\mathrm{H}$, et al.Malignant Rhabdoid Tumours of the Kidney (MRTKs), Registered on Recent SIOP Protocols From 1993 to 2005: A Report of the SIOP Renal Tumour Study Group. Pediatr Blood Cancer 2011; 56:733-7

6. Hong CR, Kang HJ, Ju HY, et al. Extra-cranial Malignant Rhabdoid Tumor in Children: A Single Institute Experience. Cancer Res Treat 2015; 47: 889-6

7. Madigan CE, Armenian SH, Malogolowkin MH, Mascarenhas L. Extracranial Malignant Rhabdoid Tumors in Childhood. The Children's Hospital Los Angeles Experience. Cancer 2007; 110: 2061-6

8. Sultan I, Qaddoumi I, Rodr iguez-Galindo C, Nassan A, Ghandour K, Al-Hussaini M. Age, Stage, and Radiotherapy, But Not Primary Tumor Site, Affects the Outcome of Patients with Malignant Rhabdoid Tumors. Pediatr Blood Cancer 2010; 54: 35-40

9. Hilden JM, Meerbaum S, Burger P, et al. Central Nervous System Atypical Teratoid/Rhabdoid Tumor: Results of Therapy in Children Enrolled in a Registry. J Clin Oncol 2004; 22: 2877-84

10. European Rhabdoid Registry V4 2015 Part II: is:epi:Concencus Therapy Recommendations for Patients with Rhabdoid Tumors of the Kidney. 2015; v4: 129-249

11. Kato $\mathrm{M}$, Koh $\mathrm{K}$, Oshima $\mathrm{K}$, et al.Long-term survivor of relapsed stage IV malignant rhabdoid tumor of the kidney. Pediatr Int 2013; 55: 245-8

12. Jayaram G, Looi ML. Malignant rhabdoid tumor of the kidney: report of a case showing focal glomeruloid differentiation. Malaysian $\mathrm{J}$ pathol 1994; 16: 83 - 7 